\title{
INDONESIAN EFL STUDENTS' PERSPECTIVES TOWARDS LEARNING MANAGEMENT SYSTEM SOFTWARE
}

\author{
Emiliana Putri ${ }^{1}$, Fatimah Mulya Sari ${ }^{2}$ \\ Universitas Teknokrat Indonesia ${ }^{1,2}$
}

emilianaputri074@gmail.com¹, fatimah@teknokrat.ac.id²

\begin{abstract}
Received: 6 May 2020 Accepted: 12 June 2020

Abstract

The use of strategy takes an important role in language learning. The use of Learning Management System software (LMSs) in the EFL classroom enables the students to get their target language. LMSs has a feature that can enhance communication between student to student and between lecturer and students. This study generally explores students' perspectives toward the use of LMSs as a language learning strategy. This qualitative research was conducted in Universities in Lampung Province, Indonesia. The subjects were 33 undergraduate students in the English Education study program, Faculty of Arts and Education. The data used were questionnaires and interviews. The findings show that the participants give positive feedback toward their experiences in using LMSs. By using LMSs, admitted that LMSs was given improvement to their speaking, reading, listening, and writing skill. However, some students revealed that there were some technical problems founds when they use LMSs, such as bad gateway connection. Nevertheless, learning a language using LMSs as the strategy helps the students to have self-learning experiences.
\end{abstract}

Published: 27 June 2020

Keywords: learning management system, language learning strategies, students' perspective.

\section{To cite this article:}

Putri, E. \& Sari, F. M. (2020). Indonesian EFL Students' Perspectives towards Learning Management System Software. Journal of English Language Teaching and Learning, 1(1), 20-24.

\section{INTRODUCTION}

In a formal educational context, teaching and learning process certainly requires a suitable learning strategy to achieve the learning objectives (Mandasari and Oktaviani, 2018), on the other side, it also needs interaction to create the successful interactive systems and interaction design (Sari, 2018) to promote its process in the classroom. Language learning strategies play an important role to succeed in the process of language learning in the class. Even though it was commonly interchangeable with the terms learning style (Wahyudin and Rido, 2020), according to Mandasari and Oktaviani (2018), several learning strategies are commonly used by learners such as affective, memory, social, metacognitive, cognitive, and compensation language learning strategies. As it occurs in Indonesian college students, the strategies are used to support the language learning process.

In the current year, the importance of language learning strategies in the EFL classrooms is increasing as with the increasing importance of language learning. Cohen (2011) defines language learning strategies as thoughts and actions, consciously chosen and operationalized by language learners, to assist them in carrying out a multiplicity of tasks from the very outset of learning to the foremost advanced levels of target language performance. As stated by Tanjung (2018), language learning strategies are conscious methods, techniques, activity, or devices that a student utilizes from preparation, process, and evaluation of their learning so they can acquire language and achieve the learning goals altogether.

The development of technology affects the changing of the teaching and learning process and provides the various learning strategies which are suitable for the learners' characteristics to make them become independent learners (Aminatun and Oktaviani, 2019; Oktaviani and Mandasari, 2020). One of the language learning strategies is blended learning or e-learning, and one of the foremost under-reported mechanics of any blended learning or e-learning environment is the learning management system (LMS). Learning Management Systems are often criticized, due to the belief that these technologies simply virtualize nonvirtual classrooms (Silva, 2013). Within the learning management system, the interaction happens through devices that enable communication, either synchronously or asynchronously. The learning management 
system allows the creation of different strategies to encourage dialogue and active participation of the learners. Learning Management System has been a crucial part of the e-learning environment. Ellis (2009) points out the basic description that LMS (Learning Management System) is a software application that automates the administration, documentation, tracking, reporting of learning programs. The learning management system may facilitate the instructors, the learners, and also the administrators, so that they are easy to use and access the services and it's beyond the restriction of your time and place in the teaching and learning process. As it is also stated by Sari and Putri (2019) that the learners should be provided with a userfriendly instructional learning media to help them build their knowledge of the language.

There is several hottest learning management system software (LMSs) such as Moodle, Edmodo, and Blackboard. LMS software sets a framework through which learning content is being delivered and managed. The content of language learning will be managed by the instructor, and the instructors will provide each of the topics that will be discussed with the learners. The language learners can access the content of material given by the instructors everywhere and every time.

In the previous study conducted by Chaubey and Bhattacharya (2015), they are points out that the role of LMS in teaching and learning pedagogy, access and flexibility, and cost-effectiveness can be an effective way in the teaching and learning process to achieve effective learning outcomes. Besides, the technology's roles in any educational environment have significantly altered the way EFL teaching and learning are carried out (Wahyudin, 2018). This is showed that LMS can also be used as language learning strategies. Universitas Teknokrat Indonesia has already implemented the learning management system by using SPADA that can be accessed by the Moodle platform. The SPADA (In-network Learning System) is already used as the learning strategies, but how the learning management system can also be used as the language learning strategies. Therefore, this research will explore in detail how the Learning Management System on the SPADA might be used as language learning strategies in the EFL classroom.

\section{METHOD}

To explore the objectives of this study, a descriptive qualitative method was employed. The subjects were 33 students from the English Education study program, Faculty of Arts and Education, Universitas Teknokrat Indonesia. The data collections were obtained through questionnaires and interviews. The questionnaires were distributed to all respondents. The questionnaires consist of 15 statements, which included 8 technical statements and 7 educational statements. The scales of each statement are Strongly Agree (SA), Agree (A), neutral (N), disagree (D), and strongly disagree (SD). The interpretations of the questionnaire were through the level of strongly disagree (1.00-1.80), disagree (1.81-2.60), neutral/moderate (2.61-3.40), agree (3.41-4.20), dan strongly agree (4.21-5.00)

To strengthen the findings, an interview was conducted for all respondents. The interview was conducted to explore their perspectives toward the use of LMSs (Learning Management System software) as language learning strategies. The data obtained from interviews were transcribed into words to find out the results

\section{FINDINGS AND DISCUSSION}

This section discusses the findings of the study by exploring their response toward the use of LMSs (Learning Management System software) as language learning strategies. The table below describes the means to each item of the questionnaire. The detail results can be seen as follow:

Table 1. Students Responses toward the Use of LMSs as Language Learning Strategies (Technical Aspect)

\begin{tabular}{llcc}
\hline \multicolumn{1}{c}{ Statement } & \multicolumn{2}{c}{ Result } \\
& & $\boldsymbol{n}$ & mean \\
\hline $\mathbf{1}$ & The use of LMSs is easy to use. & 33 & 3.50 \\
$\mathbf{2}$ & The use of LMSs is an effective learning strategy. & 33 & 3.31 \\
$\mathbf{3}$ & The use of LMSs is easily available and downloadable. & 33 & 3.50 \\
$\mathbf{4}$ & LMSs has already been used as a teaching-learning tool. & 33 & 3.63 \\
$\mathbf{5}$ & LMSs can be accessed everywhere and anytime & 33 & 3.60 \\
$\mathbf{6}$ & LMSs uses lots of internet data. & 33 & 3.41 \\
$\mathbf{7}$ & LMSs makes the student's eye strain. & 33 & 3.31 \\
$\mathbf{8}$ & Bad gateway often occurs in LMS. & 33 & 3.48 \\
\hline
\end{tabular}

Based on the results, there were various responses from the respondents. Table 1 describes the differences for each percentage which are very slight. Most of their responses to each statement given were agree. The highest mean was in statement 4 with the mean score of 3.63, which meant that the students agreed that LMSs has already been used as a teaching-learning tool. While, the lowest means were statement 2 and statement 7 with the same mean, 3.31 points. Statement 2 and statement 7 were indicated that the students were given a neutral response to the statement that LMSs is an effective learning strategy and the LMSs makes the student's eye strain. The other responses from statement 1 and statement 3 have gained the same mean score for 3.50 points. The students agreed 
that the use of LMSs is easy, easily available, and downloadable. Statement 5 gets a mean score of 3.60 which stated that these strategies can be accessed easily - every time and anytime. Besides, statement 6 (mean score of 3.41) and statement 8 (mean score of 3.48) show the results that the students agreed that these strategies consume much internet data and often occur a bad gateway system.

Moreover, table 2 also describes the results of students' responses to the use of LMSs as language learning strategies in the view of educational aspects. Seven statements present the results from the questionnaires. The results can be seen as follows:

Table 2. Students Responses toward the Use of LMSs as Language Learning Strategies

\begin{tabular}{llll}
\hline \multicolumn{1}{c}{ Statement } & \multicolumn{2}{c}{ Result } \\
& \multicolumn{1}{c}{ mean } \\
\hline 1 & LMSs is an interesting teaching platform & 33 & 3.19 \\
2 & LMSs creates interaction between students. & 33 & 3.04 \\
3 & LMSs creates interaction with the facilitator (lecturer). & 33 & 3.16 \\
4 & LMSs shares the learning material. & 33 & 3.60 \\
5 & LMSs is an appropriate platform for further practicing the & 33 & 3.31 \\
$\quad \begin{array}{l}\text { target language. } \\
6\end{array}$ & 33 & 3.46 \\
& $\begin{array}{l}\text { There is a sufficiency of the time to finish tests and } \\
\text { assignments. }\end{array}$ & 33 & 3.41 \\
& $\begin{array}{l}\text { The assignment given in LMSs is more difficult than the } \\
\text { assignment given in the classroom. }\end{array}$ \\
\hline
\end{tabular}

In the educational aspect, most of the students give a neutral response to the statement given. Statement 4 was the highest mean with a result of 3.60. It is indicated that students were agreed that LMSs shares learning material. It means that LMSs has provided material for the students, support from statement 3 in the technical section (table 1) that LMSs is easily available and download-able, which means that LMSs facilitate the students in their language learning process. While the lowest mean was statement 2 with the result 3.04. The students gave a neutral response toward the statement LMSs creates interaction between students.

To strengthen the results, all students were interviewed for several questions related to their experiences using LMSs as language learning strategies in their EFL classroom. From the interview, it was found out that most students discovered several advantages of using LMSs.

Firstly, there were some students stated that LMSs was easy to use and access. The following extracts described their positive responses toward the use of LMSs.

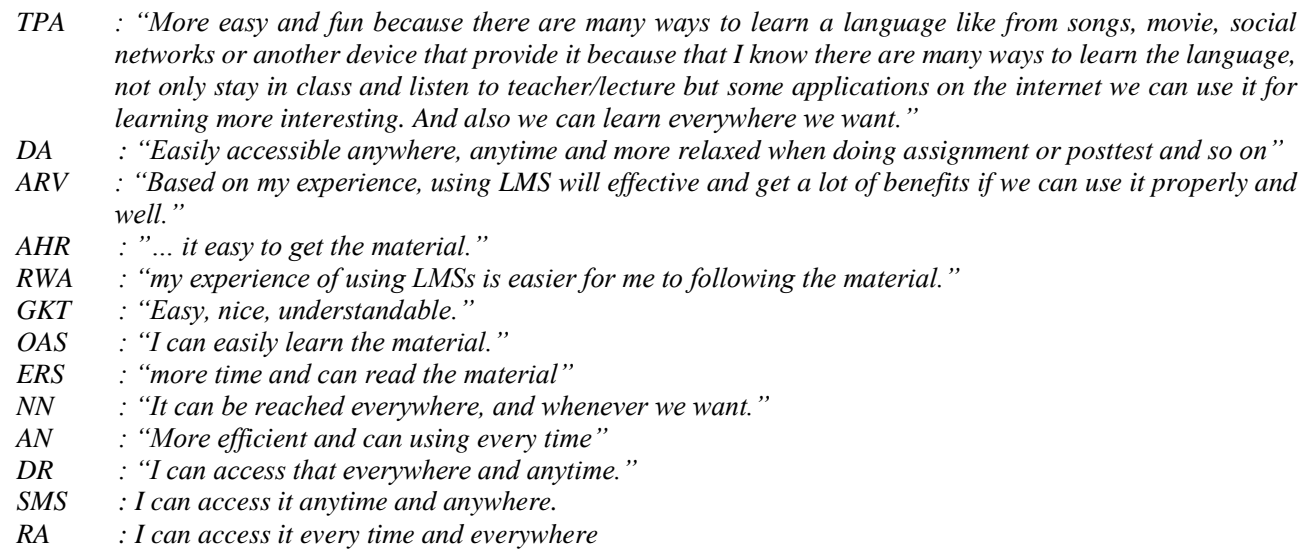

Besides, it was admitted that LMSs (Learning Management System software) help the students in their language learning. The responses might be seen in the following extracts.

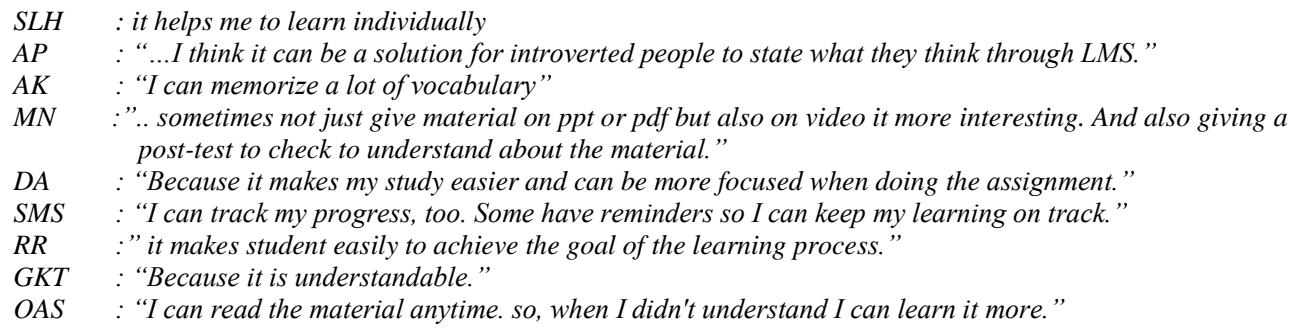

The use of LMSs is also helping the students to improve their target language in some aspects. The result of the interview described below. 


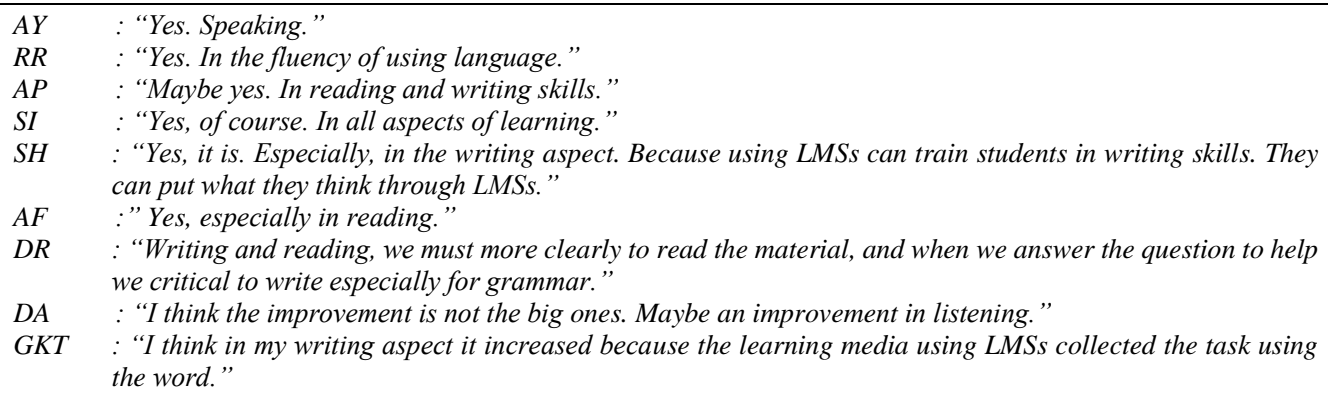

In the interview, the students also mention that there are some advantages to using LMSs. Most of them stated that they were provided some interesting materials and got much information from the provided learning materials,. They also said that they could use the LMSs anywhere and anytime as long as they had the internet data. Here are the responses that describe in the extract.

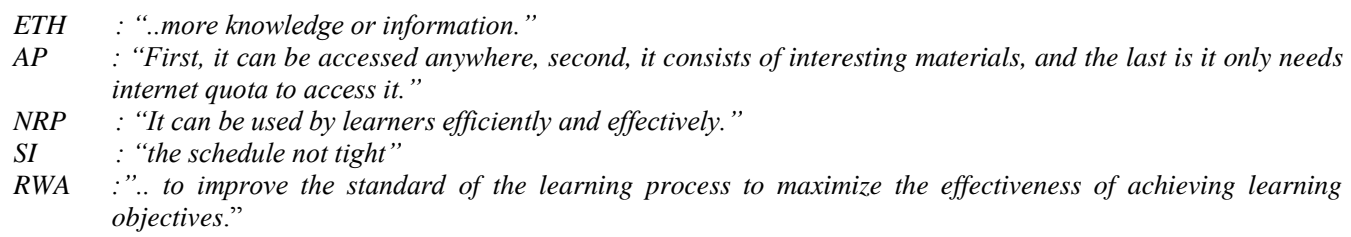

Besides the positive responses, the students also gave their responses to their difficulties in using LMSs. Most of the difficulties are about internet connections. The LMSs sometimes has bad gateway conditions. The responses are described below.

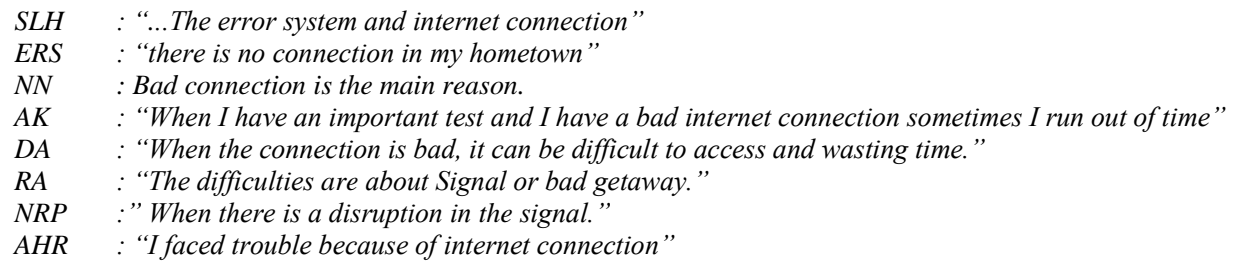

This study is designed to explore students' perspectives toward the use of LMSs as their language learning strategies. The LMSs has already been used as their learning media. Overall, the findings found out that the students give positives feedback toward the use of LMSs. It all can be seen from points of technical aspect and educational aspect. Most of their responses were agreed toward the statements given, and the rest was neutral. They gained the simplicity and convenience in utilizing a LMSs. Through LMSs, the students can get easy to access the material and it can be done everywhere and every time. The learning process through LMSs is furthered by the lecturer's guidance. In the daily activity, the students were instructed to access the subjects based on the schedule. The lecturer will provide material in the form of ppt, pdf, or video that can be accessed by the students. Supported by Bouhnik and Deshen (2014) that by uploading and sharing its material, it ensures every student gets the message to download the files. In some subjects, there are also pre-test and post-test to check the understanding of the students. Thus, LMSs is a convenient strategy to use in the language learning process.

\section{CONCLUSION}

Through the results, it can be concluded that LMSs might be used as language learning strategies in the EFL classroom. Almost all participants, using LMSs as language learning strategies give positive experiences. Besides, there were also some goals achieved from the use of LMSs, such as sharing and using learning material, enhancing communication between student to student, and between students to the lecturer. The participants revealed that LMSs is an easy and interesting platform. They also admitted that LMSs affect the improvement of their speaking, reading, listening, and writing skills. Language lecturer takes an important role in the use of LMSs, how the lecturer gives clear instruction to the students lead the understanding of the students.

\section{REFERENCES}

Aminatun, D. \& Oktaviani, L. (2019). Memrise: Promoting Students' Autonomous Learning Skill through Language Learning Application. Metathesis: Journal of English Language Literature and Teaching, 3(2), 214-223.

Bouhnik, D. \& Deshen, M. (2014). WhatsApp Goes to School: Mobile Instant Messaging between Teachers and Students. Journal of Information Technology Education: Research, 13, 217-231. Retrieved from: http://www.jite.org/documents/Vol13/JITEv13ResearchP217-231Bouhnik0601.pdf 
Chaubey, A. \& Bhattacharya, B. (2015). Learning Management System in Higher Education. IJSTE - International Journal of Science Technology \& Engineering, 158-162.

Cohen, A. (2011). Strategies in learning and using a second language ( $\left.2^{\text {nd }} e d.\right)$. Longman.

Ellis, R. K. (2009). A Field Guide to Learning Management System. American Society for Training and Development.

Mandasari, B. \& Oktaviani, L. (2018). English Language Learning Strategies: An Exploratory Study of Management and Engineering Students. Premise: Journal of English Education and Applied Linguistics, 7(2), 61-78.

Oktaviani, L. \& Mandasari, B. (2020). Powtoon: A Digital Medium to Optimize Students' Cultural Presentation in ELT Classroom. Teknosastik, 18(1), 33-41.

Oliveira, P. C. D., Cunha, C. J. C. D. A., \& Nakayama, M. K. (2016). Learning Management Systems (LMS) and E-Learning Management: An Integrative Review and Research Agenda. JISTEM - Journal of Information Systems and Technology Management, 13(2), 157-180.

Sari, F. M. (2018). Patterns of Teaching-Learning Interaction in the EFL Classroom. Teknosastik: Jurnal Bahasa dan Sastra, 16(2), 41-48.

Sari, F. M. \& Shely, N. P. (2019). Academic Whatsapp Group: Expressing Students' Experiences in Writing Class. Teknosastik: Jurnal Bahasa dan Sastra, 17(2), 56-65.

Sari, F. M. \& Wahyudin, A. Y. (2019). Blended-Learning: The Responses from Non-English Students in the Indonesian Tertiary Context. Teknosastik: Jurnal Bahasa dan Sastra, 17(1), 23-28.

. (2019). Undergraduate Students' Perceptions toward Blended Learning through Instagram in English for Business Class. International Journal of Language Education, 3(1), 64-73.

Tanjung, F. Z. (2018). Language Learning Strategies In English As A Foreign Language Classroom In Indonesian Higher Education Context. A Journal on Language and Language Teaching, 21, 50-68.

Wahyudin, A. Y. (2018). The Impact of Online Peer Feedback on EFL Students' Writing at Tertiary Level. BAHTERA: Jurnal Pendidikan Bahasa dan Sastra, 17(1), 1-10.

Wahyudin, A. Y., \& Rido. A. (2020). Perceptuals learning styles preferences of international master's students in Malaysia. BAHTERA : Jurnal Pendidikan Bahasa Dan Sastra, 19(1), 95-103. https://doi.org/10.21009/bahtera.191.10.

\section{BIOGRAPHY OF AUTHORS}

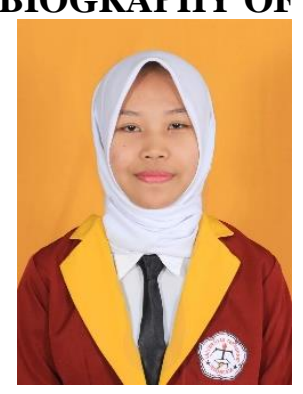

Emiliana Putri is an active student in the English Education study program, Faculty of Arts and Education, Universitas Teknokrat Indonesia. During her study, she actively joins the students' organization.

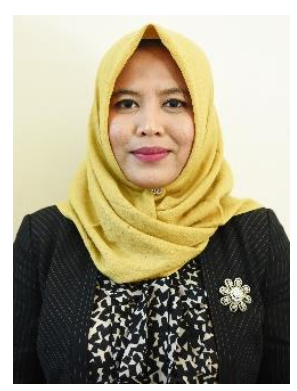

Fatimah Mulya Sari is an English Education Lecturer in the Faculty of Arts and Education, Universitas Teknokrat Indonesia. She discovers what she loves most about her works and where she hopes to take her career. She completed her Master's degree in Universitas Sebelas Maret in 2015. Her research interests are English language teaching, classroom interaction, classroom management, online/blended learning, and teaching methods. Recently, she is now the head of the Center for Education and Social Sciences, Universitas Teknokrat Indonesia. 